\title{
Kırgızistan Sağlık Turizmi Kapsamında At Sütü Tedavisine Alternatif Olarak Eşek Sütünün Kullanımı ve Önemi ${ }^{1}$
}

\author{
Öğr. Gör. Nadira TURGANBAYEVA \\ Kırgızistan-Türkiye Manas Üniversitesi, Turizm ve Otelcilik Yüksekokulu \\ nadira.turganbaeva@manas.edu.kg \\ https://orcid.org/0000-0002-7620-9236 \\ Araş. Gör. İbrahim GÜNDOĞDU \\ Kırgızistan-Türkiye Manas Üniversitesi, Turizm ve Otelcilik Yüksekokulu \\ ibrahim.gundogdu@manas.edu.kg \\ https://orcid.org/0000-0003-1360-1924 \\ Dr. Öğr. Üyesi Hakkı ÇILGINOĞLU \\ Kastamonu Üniversitesi, Turizm Fakültesi \\ hcilginoglu@kastamonu.edu.tr \\ https://orcid.org/0000-0002-6787-3397 \\ https://doi.org/10.37847/tdtad.660734
}

\section{Özet}

Sağlık turizmi dünyada olduğu gibi Kırgızistan' da da önemli bir sektör durumuna gelmiştir. Özellikle at sütü (kımız) ve termal turizm en çekici sağlık turizmi türleri arasındadır. Kırgızistan önemli termal kaynaklara sahiptir. Ancak sağlık turizmi açısından farklılık yaratabilecek alternatiflerde at sütü öne çıkmaktadır. At sütü (kımız) Kırgız halkı arasında yaygın olarak tedavi amacıyla kullanılmaktadır. Kırgızistan'da hem at sütü tedavisi sunabilen ve hem de konaklama yapılabilen tesisler mevcuttur. Başta yerli turistler olmak üzere çok sayıda insan her yıl bu tesislerde konaklamaktadır. Yapılan araştırmalar sonucunda son yıllarda tedavi amaçlı eşek sütü kullanımı da yaygınlaşmaya başlamıştır. $\mathrm{Bu}$ bağlamda sağlık turizmi kapsamında Kırgızistan'da var olan at sütüne alternatif olarak eşek sütünün de değerlendirilmesi Kırgızistan ekonomisine önemli katkı sağlayacaktır. Bu çalışmada ikincil kaynaklardan yararlanılarak eşek sütünün içeriği ve önemi anlatılmaya çalışılmıştır. Ayrıca Bişkek'te doğal ortamda yaşayan eşeklerden süt örneği alınmış, laboratuvar ortamında analiz edilmiş ve içeriği değerlendirilmiştir. Sonuç olarak eşek sütü ile ilgili yapılan çalışmalarda eşek sütünün içeriğinde protein, laktoz, doymamış yağ asitleri ve kolesterolün düşük olması, serum proteinlerinin ise yüksek olması gibi özellikleri açısından anne sütüne benzediği görülmüştür. Aynı şekilde, serum proteinleri, lizozim, laktoferrin gibi özellikleri ile de kısrak (at) sütüne benzer özellikler taşıdığı görülmüştür. Bu nitelikleri ile eşek sütü, sindirim sistemi rahatsılılılarında, tümör tedavisinde, astım hastalıkları tedavisinde kullanılabileceği düşünülmektedir. Laboratuvar sonuçları göz önüne alındığında ilgili literatürü desteklediği sonucuna ulaşılmıştır. Kırgızistan'da eşek sütü tedavisinin kımız tedavisi ile birlikte verilmesi turizm için yeni bir çekicilik oluşturacaktır.

Anahtar Kelimeler: Sağlık Turizmi, Eşek Sütü, Alternatif Sağlık Turizmi, Kımız, Kırgızistan’da Turizm.

\footnotetext{
${ }^{1}$ Bu makale 23-25 Kasım 2017 tarihlerinde Kastamonu'da düzenlenen “1. Uluslararası Sürdürülebilir Turizm Kongresi”nde sunulan ve bildiriler kitabında yer alan bildirinin geliştirilmiş halidir.
}

July-2020 Vol:5 No:1 International Journal of Turkic World Tourism Studies 


\title{
The Use and Importance of Donkey Milk as an Alternative to Horse Milk Treatment within the Scope of Kyrgyzstan Health Tourism
}

\begin{abstract}
Health tourism has become an important sector in Kyrgyzstan as well as in the world. In particular, horse milk (koumiss) and thermal tourism are among the most attractive health tourism types. Kyrgyzstan has important thermal resources. However, horse milk stands out in alternatives that may make a difference in terms of health tourism. Horse milk (red) is widely used among Kyrgyz people for treatment purposes. Kyrgyzstan has facilities for both horse milk treatment and accommodation. Many people, especially local tourists, stay in these facilities every year. As a result of the researches, the use of donkey milk for therapeutic purposes has become widespread in recent years. In this context, evaluation of donkey milk as an alternative to horse milk in Kyrgyzstan within the scope of health tourism will make an important contribution to the economy of Kyrgyzstan. In this study, the related literature is examined and the content and importance of donkey milk is tried to be explained. In addition, milk samples were collected from donkeys living in Bishkek in the natural environment, analyzed in the laboratory and its contents were evaluated. As a result, it has been found that donkey milk is similar to mother's milk in terms of low protein, lactose, unsaturated fatty acids and cholesterol levels and high serum proteins. Similarly, serum proteins, lysozyme and lactoferrin were found to be similar to mare (horse) milk. With these qualities, donkey milk is thought to be used in digestive system disorders, tumor treatment and asthma diseases. When the laboratory results are considered, it is concluded that it supports the relevant literature. Donkey milk treatment with Koumiss treatment will create a new attraction for tourism in Kyrgyzstan.
\end{abstract}

Keywords: Health Tourism, Donkey Milk, Alternative Health Tourism, Koumiss, Tourism in Kyrgyzstan.

\section{Giriş}

İnsanlar geçmişten bugüne sağlıklarını kaybettiklerinde buna çare bulabilmek için farklı arayışlara girmişlerdir. Bu arayışların bir sonucu olarak sürekli yaşanılan, ikamet edilen yerden başka yerlere tedavi olabilmek amacıyla çeşitli seyahatler meydana gelmiştir. Günümüzde bu seyahatler sağlik turizmi adı altında devam etmektedir. Kırgızistan'da sağlık turizm kapsamında termal turizm ve at sütü tedavisi ilk akla gelenlerdir. Kırgizistan'da önemli termal kaynaklar bulunmaktadır. Bu termal kaynakların bulunduğu yerlerde ise kurortlar ve sanatoryumlar kurulmuş, insanlar bu tesislerde termal kaynaklardan yararlanmaktadırlar (Erdem ve Gündoğdu, 2018). Aynı zamanda bu ve kımız tedavisi sunmak için açılan tesislerde bahar ve yaz aylarında kımız tedavisi hizmeti verilmektedir.

Kırgızistan'da at yetiştiriciliği özel bir konuma sahiptir. Kırgızların atla olan ilişkisinin çok eski tarihlere dayandığı söylenebilir (Belek, 2017). Özellikle kırsal bölgelerde at Kırgızlar için vazgeçilmezdir. Kırgızistan' da at sütünün tedavi amacıyla kullanımı yaygın olmasına ve süt üreten at sayısının sürekli artmasına rağmen tedavi amacıyla üretilen sütü işlemek için tesis sayısında yeterli artış mümkün olmamıştır.

Kısrak (dişi at) sütünün tüketimi ülkenin doğal güzellikleri ve temiz havasıyla bilinen dağların çevresinde, tedavi merkezlerinde ilk bahardan sonbaharın başlangıcına kadar yerli ve yabancı turistler tarafından ilgi görmektedir. Son yıllarda ise kısrak sütüne ve anne sütüne içerik olarak yakın olan eşek sütü, Kırgızistan'da ilgi çekmeye başlamıştır. Kırgızistan' da ne kadar eşek sütüne bakış olumsuz

July-2020 Vol:5 No:1 International Journal of Turkic World Tourism Studies 
olsa da kanser hastalığının tedavisinde çok olumlu sonuçları nedeniyle eşek sütüne ilgi her yıl artmaktadır. Bu nedenle son yıllarda at yetiştiriciler ve kımız üreten tesisler eşekleri de yetiştirmeye başlamışlardır. Eşek sütüne ilginin artmasına rağmen gün geçtikçe eşeklerin sayılarının azalması ilgi uyandırmaktadır. Kırgızistan'da 2016 yıllına kadar eşek sayısı 43040 iken 2016 yılı itibariyle \%19,5 düşmüştür (Kırgız Cumhuriyeti Milli İstatistik Komitesi Turizm Verileri, 2016).

Eşekler (Equus asinus) dünyada ilk olarak Mısır ve Mezopotamya'da MÖ 5000 civarında, evcilleştirilmiş ve dünyaya yayılmıştır. Eşeklerin evcilleştirilmesi, sığır, koyun ve keçilerin Mısırlı Nubyalılar tarafindan evcilleştirilmelerinden daha sonra gerçekleşmiştir. Eşek, Eski Mısır'daki insanlar tarafından yük taşıyıcısı olarak kullanılmıştır. Eski Mısır'daki eşeklerin yaklaşık 1.2 metre yüksekliğinde ve 272.16 kilogram ağırlığında, yani modern eşeğimizden çok daha büyük olduğu yapılan araştırmalarda ortaya çıkmıştır. Yine yapılan araştırmalar sonucunda o yıllarda eşeklerin sürü olarak dolaşmasına izin verildiği ve eşeklerin sütlerinden yararlanıldığ 1 görülmüştür (Attia, 2017). Blench (2012) eşeklerin Afrika'da iş hayvanları, üretim, sağım ve yemek amacıyla kullanıldığını söylemektedir. Günümüzde ise eşeklerin sütünün tıbbi etkisi olduğu eşek sütüne ilgiyi arttırmıştır. İtalya ve başka Avrupa ülkelerinde eşek çiftlikleri genişletilmekte ve 'onotherapy' prosedürleri çok yaygınlaşmaktadır. 'Onotherapy-onos' Yunanca'da eşek, 'therapy' ise tedavi anlamına gelir ve insanların hayvanlarla iletişim yoluyla terapisi olarak tanımlanmaktadır (Karatosidi, 2013). Örneğin Kıbrıs'ta 'Dipotamos' ve 'Arrivo' adında ilgi çekici eşek çiftlikleri bulunmaktadır. Buraya gelen turistler, yerel flora ve fauna ile tanışır, eşeklere biner, müzeleri ziyaret eder, eşek sütü, peyniri ve diğer ürünlerini satın alma fırsatı bulurlar. Türkiye'de de Antalya'nın ardından Ankara ve Konya'da eşek çiftlikleri kurulmuş, astım, kronik bronşit, kanser, siroz, ateş, balgam sökme, kemik erimesi gibi birçok rahatsızlıklar tedavi edilmektedir (Laleli, 2016). Bu çalışmada ikincil kaynaklardan yararlanılarak eşek sütünün faydalarının tespit edilmesi, at sütü gibi tedavi amacıyla kullanılabilmesi ve Kırgızistan'da alternatif bir sağlık turizmi türü olması için gerekli önerileri sunmak amaçlanmaktadır.

\section{Literatür}

\section{Sağlık Turizmine Genel Bakış}

Hızla gelişen dünyada her geçen gün insanların refah seviyeleri yükselmektedir. Bu sayede boş zaman kavramı ortaya çıkmıș olup turizm bir ihtiyaç haline gelmeye başlamıștır. Uluslararası turizm girișleri ve turizm gelirleri de bu bağlamda artış eğilimi göstermiștir. 2. Dünya Savașı'ndan bu yana turizme ayrılan kaynakların artırılmasının yanı sıra, ülke halkları arasındaki yakınlașmanın da önemli etkisi vardır. Bununla birlikte turizm döviz kazandırıcı yönü ile gelişmekte olan ülkeler için ümit ışığı haline gelmiştir (Yirik, 2014).

Günümüzde alternatif bir turizm çeşidi olarak ortaya çıkan sağlık turizminde insanlar kaybettikleri sağlıklarını geri kazanmak ya da var olan sağlık durumunu korumak amacıyla başka ülkeleri tercih etmekte ve bunlara ek olarak gittikleri yerde tatillerini de yapmaktadır. Bugün sağlık turizmi iki temel alana, kendini iyi hissettirme ve sağlıklı olmaya odaklanmıştır. Kendini iyi hissettirme masaj, doğal ve bitkisel maskeler ve cilt bakımı gibi insanlara kendilerini iyi hissettirecek ürün ve hizmetler sunumunu içerirken, sağlıklı olmak bazı sorunları önleyerek hem fiziksel hem de zihinsel anlamda bireylerin sağlıklarını korumalarına, kavuşmalarına yardım eden etkinlikleri içermektedir (Kozak ve Kozak, 2014).

Turizm olgusu ile ilgili olarak yapılan çok sayıda tanımda, bir seyahatin turizm olarak nitelendirilebilmesi için turistin devamlı biçimde ikamet ettiği yerden geçici bir süre ayrılması, gittiği 
yerdeki turizm işletmelerinin ürün ve hizmetlerini talep ederek ekonomik bir katk1 sağlaması ve gidilen yerdeki insanların ilişkilerinin oluşturduğu 'olaylar' öne çıkmaktadır (Erdem, Gülcan ve Chykynov, 2015). Sağl1k turizmi ise Dünya Sağl1k Örgütü'ne (2013) göre; "kaplıca veya diğer sağlık merkezlerine seyahat eden kişinin fiziksel iyilik halini geliştirmek amacıyla yapılan ziyaretlerdir". Türkiye Sağlık Turizmi Derneği’nin tanımına göre sağlık turizmi: Sağlığına kavuşmak için ikamet ettiği ülkeden başka bir ülkeye herhangi bir sebeple tedavi amaçla gidilmesidir.

\section{Sağlık Turizminin Tarihi}

Sağlık ve turizm ilişkisi pozitif ve negatif yönleri ile ortaya çıkmaktadır. Pozitif yönü ile bu ilişki turistlerin sağlık amaçlı seyahat etmeleri ve tedavileri ile ilgilidir. Negatif yönü ise turist sağlı̆̆ bakımından ortaya çıkan ilişkilerdir ki, bu durum turizme çok önemli zararlar verebilmektedir. Buna verilebilecek en iyi örnek ise 2002 yılında uzak doğu ülkelerinde yaşanan SARS hastalığı vakasıdır. Dünya Seyahat ve Turizm Konseyi'nin (WTTC) tahminlerine göre bu hastalık Çin, Hong Kong, Vietnam ve Singapur gibi ülkelerde 20 milyar dolarlık gelir kaybına ve 3 milyon endüstri çalışanının işsiz kalmasına neden olmuştur (İçöz, 2009). Geçmişten günümüze insanlar sağlıklarını kaybettikleri zaman çare bulabilmek için farklı arayışlara girmektedir. Bu arayışların başında da yaşadıkları yerlerden başka yerlere tedavi olabilmek amaciyla seyahat etmeleri gelmektedir. Türkiye Seyahat Acenteleri Birliği'nin (TÜRSAB) sağlık turizmi raporunda, sağlık turizminden Antik Yunan'dan bu yana bilinen bir turizm türü olarak bahsedilmektedir. Yunan hastaların o dönem yollara dökülerek Epidauria adlı kasabaya akın ettikleri bilinmektedir. Bu kasabanın adı sağlık tanrısı Asklepios'un yaşadığı yer olarak da geçmektedir. İlerleyen yüzyıllarda da şifa arayan hastalar SPA ya da sanatoryumların bulunduğu yerlere seyahat etmişlerdir (Türsab Sağlı Turizmi Raporu, 2013). Başka kaynaklarda ise sağlık turizminin antik uygarlıklara dayandığından bahsedilmektedir. Bu uygarlıklar arasında Sümerlerin sıcak kaynakların etrafında bilinen en eski sağlık tesislerini inşa ettiği ve bu tesislerin su akan havuzlar içeren çok büyük tapınaklar olduğu belirtilmektedir (Sağlık Turizmi Derneği, Türkiye Sağlık Vakfı. 2010). Rönesans ile birlikte de Avrupa ve İngiltere'de sadece sanat ve kültürün yeniden doğuşu gerçekleşmemiş, aynı zamanda sağlık turizmi de ortaya çıkmıştır. Örneğin 1326 yılında keşfedilen Sular Kasabası demir zengini sıcak su kaynaklarına sahip olduğu için Avrupa'da kısa sürede ün kazanmış ve I. Petro ve Victor Hugo gibi kişiler burayı ziyaret etmiştir. Yine 16. yüzy1lda zengin Avrupa'lılar tarafindan St. Mortiz, Ville d' Eaux, Baden Baden, Aechen ve İngiltere'deki Bath gibi SPA'lar içeren turistik kasabalar keşfedilmiştir. Örneğin daha sonra Bath şehrinde sağlık turizmi nedeniyle yollar kaldırımlarla döşenmiş, sokaklar sşıklandırılmış ve oteller ile restoranlar güzelleştirilmiştir (Zengingönül vd., 2012).

17. yüzyılda Yeni Dünya'nın keşfi ile birlikte İngiliz ve Hollandalı kolonistler Amerika yerlilerinin iyileştirme konusunda iyi olduklarını görmüşler ve mineral su kaynaklarına yakın ahşap kabinler yapmışlardır. Çünkü bu bölgede yaşayan bireylerin bitkisel tıp konusundaki bilgilerinin Avrupa, Asya ve Afrika'dakilerle kıyaslanacak kadar iyi olduğu görülmüştür. Bu da Avrupa'daki sağlık yolcuları için yeni duraklar yaratmıştır. İnsanlar verem gibi hastalıklarına çare bulabilmek amacıyla 18. ve 19. yüzyıllarda buralara gitmeye devam etmişlerdir. Bugün dünyada en çok gidilen sağlık turizmi destinasyonları arasında Türkiye, Güney Kore, Hindistan, Meksika, Tayland, İsrail, Malezya, Singapur gibi ülkeler geliyor. Sağlık turizmi çalışmaları tıp turizmi, termal turizm, yaşlı ve engelli turizmi olarak geniş kapsamlı olarak yürütülüyor (Henderson, 2014; Barnato, 2018).

\section{Sağlık Turizmi Türleri ve Medikal Turizm}

Ruhsal ve bedensel rahatsızlıkları bulunan bireylerin evlerinden ayrılıp değişik bölgelerde tedavi görme istekleri sağlık turizm türlerinin doğmasını sağlamıştır. Sağlık turizmi faydalanma şekillerine

July-2020 Vol:5 No:1 International Journal of Turkic World Tourism Studies 
göre alt gruplara ayrılmaktadır. En bilinen türü ise medikal turizmdir. Medikal turizme ek olarak kaplıcalar yani termal turizm, yaşlı ve engelli rehabilitasyon merkezleri ve sağlık alanında hizmet veren cerrahi merkezler de sağlık turizminin alt dalları olarak incelenmektedir (Çevirgen, 2014).

$\mathrm{Ne}$ var ki eşek sütü ve kımız tedavisinin hastane ortamında alınması bir zorunluluk değildir. Günümüzde Orta Asya' daki birçok ülkede, özellikle kırsal bölgelerde faaliyet gösteren küçük ve orta ölçekli konaklama işletmelerinde kımız tedavisi hizmeti sunulduğu bilinmektedir (Erdem ve Gündoğdu, 2018). Bu bağlamda kımız tedavisi almak amacıyla hareket eden turistlerin temel seyahat motivasyonlarından birinin, çeşitli rahatsızlıklarına çözüm bulmak için tıbbi tedaviye erişmek olduğu söylenebilir. Dolayısıyla eşek sütü tedavisi de benzer rahatsızlıklara çözüm bulmak isteyen turistlerin yapacağı seyahatler sonucu gerçekleşecektir. Bu varsayımla eşek sütü ve kımız tedavileri medikal turizm kapsamına giren bir olgu olarak nitelendirmek yanlış olmayacaktır.

Medikal turizmi genellikle yüksek gelirli ülkelerden düşük ve orta gelirli ülkelere daha ucuz sağlık hizmeti almak için yapılan seyahatler olarak betimlemiştir. Bu seyahatler aynı ülkede iller arası olabileceği gibi uluslararası seyahat şeklinde de meydana gelebilmektedir. Yazar bu bağlamda, medikal turizm dendiğinde tıbbi tedavi hizmetlerinin akla gelmesi gerektiğini belirtmektedir (Kördeve, 2016).

\section{Kırgızistan'da Sağlık Turizmi}

Kırgız Cumhuriyeti Milli İstatistik Komitesi’nin 2016 yılı turizm raporuna göre, ülkede turizm sektöründe faaliyet gösteren kayıtlı turizm işletmelerinin türlerine göre dağılımı Tablo 2'deki gibidir.

Tablo 2'de de görüldüğü gibi Kırgızistan'da faaliyet gösteren turizm işletmeleri arasında en yüksek sayıy seyahat acenteleri sahiptir. Kırgızistan'da 2016 yıl1 itibariyle 2402 seyahat acentesi faaliyet göstermektedir. Bunu 424 işletme ile restoranlar takip etmektedir. Kırgizistan Milli İstatistik Komitesi turizm verilerinde ülkede konaklama işletmeleri için ayrı bir kategori oluşturulmadığ dikkati çekmektedir. Tablo 2'deki verilerden hareketle, 2016 y1lı itibariyle Kırgızistan'da 168 otelin faaliyet gösterdiği anlaşılmaktadır. Ancak Sanatoryum ve Kurort adı verilen tesisler de birer konaklama işletmesi olarak nitelendirilebilir. Çünkü Kırgızistan'da bu şekilde adlandırılan tesisler temel sağlık hizmetlerine odaklanarak misafirlerine konaklama olanağı sunmaktadırlar. 2016 yılı itibariyle Kırgızistan'da bu şekilde hizmet veren 75 işletme bulunmaktadır. Tablo 2'deki verilerden hareketle, Kırgızistan'da son beş yıllık periyotta Sanatoryum ve Kurortlar ve Doğa Koruma Alanları ve Milli Parklar dışındaki diğer turizm işletmelerinin sayısında düzenli bir artış trendi yaşandığını söylemek mümkündür.

Tablo 1. Kırgızistan'da Faaliyet Gösteren Kayıtlı Turizm İşletmeleri

\begin{tabular}{|l|c|c|c|c|c|}
\hline \multicolumn{1}{|c|}{ İşletme Türü } & $\mathbf{2 0 1 2}$ & $\mathbf{2 0 1 3}$ & $\mathbf{2 0 1 4}$ & $\mathbf{2 0 1 5}$ & $\mathbf{2 0 1 6}$ \\
\hline Oteller & 132 & 142 & 146 & 157 & 168 \\
\hline Turizm İşletmeleri ve Dinlenme Tesisleri & 188 & 202 & 210 & 224 & 230 \\
\hline Restoranlar & 357 & 380 & 393 & 411 & 424 \\
\hline Seyahat Acenteleri & 1925 & 2049 & 2172 & 2274 & 2402 \\
\hline Sanatoryum ve Kurortlar & 73 & 74 & 75 & 73 & 75 \\
\hline Doğa Koruma Alanları ve Milli Parklar & 19 & 19 & 19 & 19 & 19 \\
\hline Toplam & $\mathbf{2 6 9 4}$ & $\mathbf{2 8 6 6}$ & $\mathbf{3 0 1 5}$ & $\mathbf{3 1 5 8}$ & $\mathbf{3 3 1 8}$ \\
\hline
\end{tabular}

Kaynak: Kırgız Cumhuriyeti Milli İstatistik Komitesi, 2016, http://stat.kg/en/statistics/turizm/

Kırgızistan'daki bu sanatoryum ve kurortlarda kımız tedavisi çok yaygınlaşmıştır. Kımız Kırgızistan'ın ulusal içeceğidir ve sağlığa yararlı olduğu bir çok çalışmada ispatlanmıştır (Tegin, 
Gönülalan, 2014; Kırdar, 2017). Kırgızistan'a komşu ülkelerden yüzlerce turist kımız tedavisi almak amacıyla gelmektedir. Bu sayede ülke ekonomisine katkı sağlanmaktadır. Bunun gibi eşek sütünün de Kırgızistan'da gitgide yaygınlaştığı söylenilebilir.

\section{Kırgızistan'da At Sütü Kullanımı}

Rus tarih kitaplarında, Kırgız Hanlarını ziyaret eden önemli misafirlere kımız ikram edildiği yazılıdır. Bunun yanında Kırgızlar kımızı bir şifa olarak da görmekte ve bazı hastalıklarda tedavi amaçlı kullanmaktadır (Akbulut, 2015).

Kırgızistan'da kımız tedavisi veya kımız terapi dönemi genellikle mayıs ayının ikinci yarısında başlamakta ve bu dönem yaklaşık iki ile dört ay arası sürmektedir. Bu dönemde kımız tedavisi almak isteyen kişiler taze kısrak sütü veya zayıf kımız (sağmal) tüketebilecekleri kımız tedavi merkezlerine gitmektedirler. Moskova merkezli uluslararası medya kuruluşu olan Sputnik'e göre Kırgızistan'da yaklaşık 17 tane kımız tedavisi hizmeti veren tesis bulunmaktadır. Bu tedavi merkezleri Görsel 2.1'de de görüldüğü gibi Kırgızistan'ın farklı bölgelerine dağılmıştır. Görsel 2.1'de mavi renkle gösterilen tesisler tamamen kımız tedavisi odaklı çalışmayıp, bu tedaviyi isteyen misafirlerine özel kımız tedavisi hizmeti vermektedir. En çok kımız tedavisi hizmeti veren tesislerin bulunduğu bölge başkent Bişkek'in de içinde bulunduğu Çüy bölgesidir. $\mathrm{Bu}$ tesislerde fiyatlar verilen hizmete göre belirlenmektedir. Ortalama bir tesiste günlük fiyatlar 1500 - 2000 Som (yaklaşık 21-29 Dolar) aralığında olup, tesisin konumuna ve sunduğu hizmetlere göre bazı tesislerde fiyatlar 13000 Som'a (yaklaşık 188 dolar) kadar çıkabilmektedir. Bu fiyatlar kişi başı olup konaklama yapılan oda, günde üç öğün yemek (kahvaltı, öğle yemeği ve akşam yemeği) ve kısrak sütünden veya sağmaldan beş kez alınan bir paketten oluşmaktadır. Burada kalan hastalar günde beş kez taze kısrak sütü veya sağmal içip tedavi olmaktadırlar. Tedavinin faydalı olabilmesi için önerilen tedavi süresinin 7 ile 10 gün arasında olduğu belirtilmektedir (Rıskulova ve Mihaylova, 2017).

Görsel 1. Kırgızistan’daki Kımız Tedavisi Tesislerin Bölgelere Göre Dağılımı

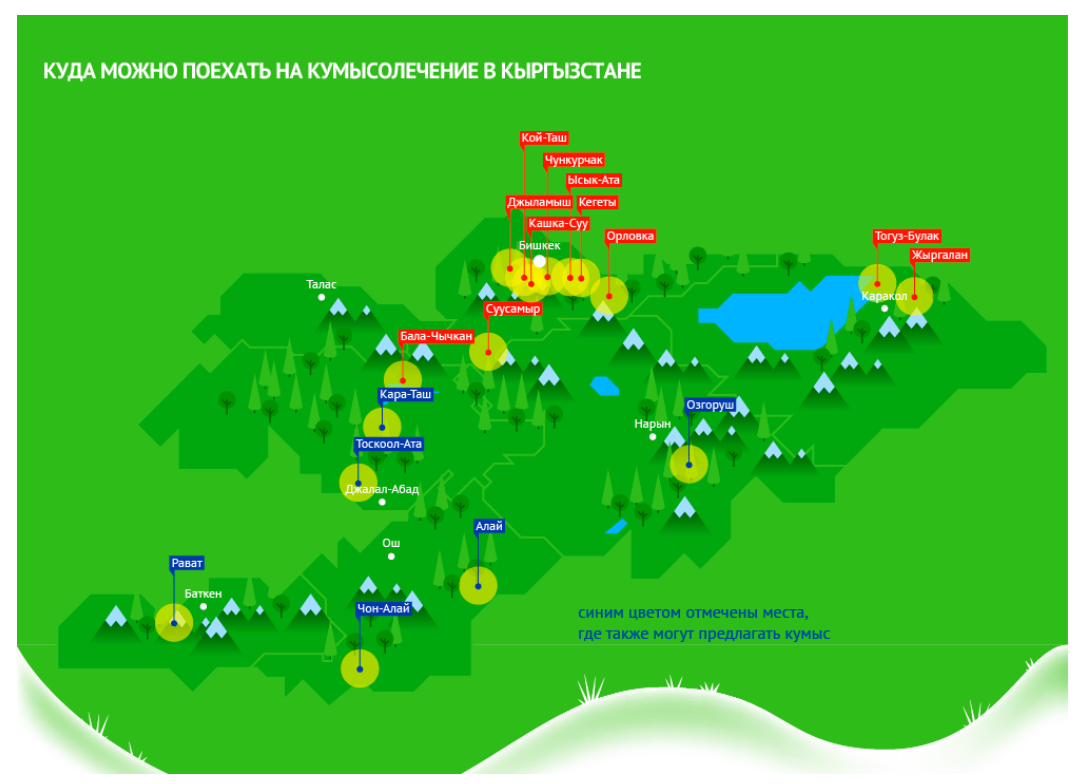

Kaynak: https://ru.sputnik.kg/infographics/20170525/1033394423/kumysolechenie-vkyrgyzstane.html 
Kırgızistan'da kımız tedavisi hizmeti sunan tesisler genellikle şehrin dışında rakımı yüksek alanlarda veya vadilerde, yani verimli meraların olduğu alanlarda kuruludur. Bunun nedeni, verimli meralarda otlayan kısrakların sütünün daha kaliteli olması ve bu sütten yapılan kımızın daha yararlı olduğudur (http://www.sayakat.kg/ru/pansionaty/kumysolechenie.html).

Kısrak sütü ve kımız içerisinde birçok mineral ve vitamin bulunmaktadır. Yapısındaki proteinlerin büyük bir kısmı mikrobiyolojik faaliyetler sonucu parçalandığından hazmı kolaydır. İçerdiği düşük oranlı alkol nedeniyle kısmen de olsa sinir sistemini olumlu yönde etkiler. İştah açıcı olan kımız mide öz suyu salgısını artırır, mide ve bağırsak hareketlerini hızlandırır. Ayrıca diğer besinlerden vücudun faydalanma kapasitesini artırır (Karagözlü, 2003).

\section{Eşek Sütü Bileşimi}

Fonksiyonel gıdaların büyük bir grubu süt ürünleridir. Süt, fizyolojik ve besinsel açıdan dengeli bir salg1 olup, yeni doğan canlıların her tülü ihtiyaçlarına uygun bir besindir. Bu açıdan bakıldığında, sağlıklı annelerin sütü bebekleri için en iyi gıdadır. Anne sütü yeni doğan bebeğin altı ay boyunca tüm ihtiyaçlarına cevap veren fizyolojik bir besindir ve her annenin sütü bebeğine özeldir. Çağlar boyu insanlar, anne sütünün bebek beslenmesinde benzersiz bir gıda olduğunu kabul etmiştir. Anne sütünü bebeklere en sağlıklı şekilde ulaştırmak ise yalnızca emzirmekle mümkündür (Irmak, 2016). Ancak, emzirmenin mümkün olmadığı durumlarda veya bebeğin sütten kesildikten sonraki yaşamında yeterli bir alternatif beslenme zorunlu hale gelmektedir (Öztürkoğlu, 2012; Чиркина, 2004). Bu nedenle İranlı bilim adamları, anne sütüne yakın olan sütleri araştırmak için, evcil hayvanların birkaç türü olan deve, eşek, kısrak ve yak sütlerini inceleyerek, eşek ve kısrak sütünün anne sütüne en yakın olduğunu kanıtlamışlardır (Nikkhah, 2011).

Tablo 2. Evcil Hayvanların Sütlerinin Ortalama Bileşimi

\begin{tabular}{|l|l|l|l|l|l|l|}
\hline Süt bileşeni & Eşek & Anne & Kısrak & Deve & Yak & İnek \\
\hline Yağ, gr & $\mathbf{1 , 1}$ & $\mathbf{4 , 0}$ & $\mathbf{1 , 3}$ & 4,5 & 6,5 & 4,0 \\
\hline Protein, gr & $\mathbf{1 , 7}$ & $\mathbf{1 , 9}$ & $\mathbf{2 , 1}$ & 3,5 & 5,1 & 3,4 \\
\hline Laktoz, gr & $\mathbf{6 , 6}$ & $\mathbf{6 , 5}$ & $\mathbf{6 , 4}$ & 4,4 & 4,4 & 4,8 \\
\hline Mineral madde, gr & $\mathbf{0 , 4}$ & $\mathbf{0 , 2}$ & $\mathbf{0 , 4}$ & 0,7 & 0,8 & 0,7 \\
\hline Kuru madde, gr & $\mathbf{1 0 , 2}$ & $\mathbf{1 2 , 1}$ & $\mathbf{1 0 , 5}$ & 12,8 & 16,9 & 13,3 \\
\hline Kolesterol, mg & $\mathbf{2 , 2}$ & $\mathbf{2 0}$ & $\mathbf{4 , 5}$ & 37 & 22 & 14 \\
\hline Kalsiyum, mg & $\mathbf{6 8}$ & $\mathbf{3 2}$ & $\mathbf{8 9}$ & 143 & 131 & 120 \\
\hline Fosfor, mg & $\mathbf{5 0}$ & $\mathbf{1 4}$ & $\mathbf{5 6}$ & 116 & 106 & 93 \\
\hline Doymuş yağ asitleri, gr & $\mathbf{0 , 4}$ & $\mathbf{1 , 8}$ & $\mathbf{0 , 4}$ & 2,4 & 3,9 & 2,4 \\
\hline Monodoyamış yağ asitleri, gr & $\mathbf{0 , 2}$ & $\mathbf{1 , 6}$ & $\mathbf{0 , 3}$ & 1,4 & 2,2 & 1,1 \\
\hline Polidoymamı̧ yağ asitleri, gr & $\mathbf{0 , 4}$ & $\mathbf{0 , 5}$ & $\mathbf{0 , 5}$ & 0,5 & 0,4 & 0,1 \\
\hline
\end{tabular}

Kaynak: Nikkhah, 2011.

Nikkhah (2011) yapmış olduğu çalışmasında eşek sütü, anne sütü, kısrak sütü, deve sütü, yak sütü ve inek sütünün içeriklerini analiz edip karş1laştırmıştır. Tablo 2'de görüldüğü gibi eşek sütü, anne sütü ve kısrak sütü çok yakın değerleri sahiptir. Ancak yă̆, kolesterol, kalsiyum, fosfor, doymuş yağ asitleri ve monodoymamış yağ asitleri arasında değerler farklılık göstermektedir.

Eşek sütü ve kısrak sütü, inek sütünden daha düşük oranda yağ, protein, kolesterol, fakat daha yüksek oranda laktoz içermekte, bu nedenle anne sütüne yakın bir bileşim sergilemektedir (Öztürkoğlu, 2012; Polidori, 2012; Muehlhoff, 2013). Eşek sütü ve kısrak sütü içerdiği laktoz miktarı, protein ve süt 
yağının yapısı bakımından anne sütüne benzemektedir. Anne, eşek ve kısrak sütünün diğer önemli bir özelliği de protein fraksiyonlarından kazein ve serum proteini miktarının yaklaşık olarak eşit olmasıdır (Kırdar, 2017). Bu nedenle bu tür sütler albümin süt adı alır. Bileşiminde kazeine yakın oranda albümin ve globülin bulunduran sütlere denir. Kısrak ve eşek sütünde bulunan yağ globülleri küçük çaplı olduğundan enzimlerin etkisiyle daha kolay sindirilir. İnek sütünün aksine yüksek moleküllü yağ asitlerini (özellikle linoleik, linolenik ve araşidonik) fazla miktarda içeren kısrak sütünün \%44,1 oranında doymuş, \%55,9 oranında ise doymamış yağ asidi içerdiği bildirilmiştir. Albümin sütlerinde (anne sütü, eşek sütü ve kısrak sütü) 4 ana serum proteini bulunmaktadır: $\alpha$ laktalbümin, $\beta$-laktoglobulin, laktoferrin ve lizozim. Bu sütlerde inek sütündekinden daha yüksek oranda protein miktarı bulunmaktadır (Salimei ve Fantuz, 2012).

Tablo 3: Eşek, Kısrak ve Anne Sütlerinin Protein Kompozisyonu

\begin{tabular}{|c|c|c|c|c|}
\hline & Kısrak sütü & Eşek sütü & Anne sütü & İnek sütü \\
\hline Kazein, mg/100g & 172 & 120 & 75 & 407 \\
\hline \multicolumn{5}{|c|}{ Kazein bileşenleri \% } \\
\hline$\alpha_{s 1}-$ kazein & 17,9 & - & 32 & 41 \\
\hline$\alpha_{\mathrm{s} 2^{-}}$kazein & 1,4 & - & Yok & 10,8 \\
\hline$\beta$ - kazein & 78,5 & - & 85 & 33 \\
\hline к- kazein & 1,8 & - & $(<\% 15)$ & 12 \\
\hline $\begin{array}{c}\text { Serum } \\
\mathrm{mg} / 100 \mathrm{~g}\end{array}$ & 130 & 107 & 97 & 99 \\
\hline Protein , \% & 38,79 & 36,96 & 53,52 & 17,54 \\
\hline \multicolumn{5}{|c|}{ Serum proteinlerin bileşeni, $\%$} \\
\hline$\alpha$-laktalbümini & 28,5 & 22,6 & 40,3 & 19,0 \\
\hline$\beta$ - laktoglobulini & 30,7 & 29,8 & - & 50,8 \\
\hline Serum albumini & 4,4 & 6,2 & 7,7 & 6,3 \\
\hline lizozim & 10,5 & 21,0 & 5,5 & İz miktarda \\
\hline İmmünoglobülinler & 19,6 & 11,5 & 15,5 & 12,7 \\
\hline laktoferrin & 7,0 & 4,48 & 26,6 & 1,6 \\
\hline
\end{tabular}

Kaynak: Salimei ve Fantuz, (2012).

Albümin sütlerin bileşiminde bulunan lizozim, kısrak ve anne sütüne kıyasla eşek sütünde yüksek miktarda bulunmaktadır. Bu durum eşek sütünün olasıllkla bakteri içeriğinin de düşük bir düzey göstermesini mümkün k1lmaktadır (Tablo 3).

\section{Eşek Sütünün Özellikleri ve Faydası}

Eşeklerin evcilleştirilmesi M.Ö. 5000'li yıllara dayanmaktadır. İnsanoğlu geçişten bu yana eşekleri farklı amaçlar için kullanmıştır. Örneğin Mısır'da Kleopatra'nın kendini güzelleştirmek için eşek sütü banyosu yaptığı araştırmalar sonucu ortaya çıkmıştır. Bugün ise Dünya'nın farklı yerlerinde eşek sütünün güzelleştirme ve kozmetik amaçla kullanılması yaygınlaşmıştır. (Budak ve Gürsel, 2012). Günümüzde eşek sütü ilgi çekmekte ve literatürde ilgili çalışmalara daha fazla rastlanmaktadır. Eşek sütünün sağlığa etkilerini araştıran çalışmalardan bazıları aşağıdaki gibidir:

Li ve arkadaşları (2017) yapmış oldukları çalışmada eşek sütü ve eşek sütü tozunun besin maddelerini ve antioksidan aktivitesini incelemişlerdir. Çalışmanın en temel bulgularından birisi eşek sütü bileşenlerinin anne sütüne çok yakın olmasıdır. Ayrıca eşek sütünde laktoz oranının yüksek olmasınden dolayı, bağırsak yolunun yararlı mikrobiyal çoğalımını teşvik edebileceği görülmüştür. Yine peynir altı suyu proteininin yüksek oranı nedeniyle, bebek midesinde eşek sütü proteini, 
sindirilmesi ve emilmesi kolay küçük ve yumuşak pıhtı oluşturabilir. Eşek sütü ve eşek sütü tozunun yağ ve kolesterol içeriğinin düşük, insan vücudunun temel yağ asitleri içeriğinin yüksek olması, kardiyovasküler hastaları, safra taşı hastaları, obezite hastaları ve yaşlılar için uygun olduğu sonucuna 1şık tutmuştur.

Tsakali ve arkadaşları (2018) bu çalışmada geleneksel materyal ve yöntemler kullanarak eşek sütünden yoğurt tarzı bir ürün üretmeyi amaçlamışladır. Ürünü eşek sütünü sade ve diğer süt ürünleriyle kombinasyon halinde üretmeyi denemişlerdir. Sonuç olarak katkı maddesi içermeyen, başka süt ilavesi ile eşek sütünden elde edilen yoğurt tarzı bir ürünün üretilmesinin mümkün olduğu ortaya çıkmıştır. Ayrıca yazarlar eşek sütünden üretilen ürünlerin tüketiciler tarafindan kabul edilip edilmeyeceğini araştırmışlardır. Araştırma sonucunda insanların eşek sütünün benzersiz özelliklerinden yararlanmak için daha fazla para harcamayı kabul ettikleri görülmüştür.

Karabagias ve Halatsi (2017) yapmış oldukları bu çalışmada eşek sütünün sağlığa faydası, potansiyel uygulamaları ve yunan ekonomisine olası katkısı üzerinde durmuşlardır. İlgili çalışmada eşek sütünün kuru cilt ve sedef hastalığı gibi çeşitli dermatolojik hastalıkların tedavisi için ideal bir gıda ürünü olduğuna değinmişlerdir. Ek olarak, dişlerin güçlendirilmesine ve eklem ağrıları, astım, mide ülseri, boğaz ağrısı gibi hastalıkların tedavisine katkıda bulunduğunu ve yaşlanma sebebiyle oluşan kırışıklıkların önlenmesine önemli ölçüde katkıda bulunduğunu belirtmişlerdir. Ayrıca modern tıbbın babası olan Hipokrat'ın, karaciğer problemleri, bulaşıcı hastalıklar, ateş, ödem, zehirlenme ve yaraların tedavisi gibi birçok hastalıkta eşek sütü kullandığını yine çalışmalarında belirtmişlerdir.

Mathusudan ve arkadaşları (2017) eşek sütünün içeri, özellikleri, besin değeri ve sağlık açısından faydalarını incelediği bu çalışmada, eşek sütünün içeriğinin anne sütüne en yakın olduğu, içerdiği bazı serum proteinlerinin akciğer kanseri tedavinde kullanılabileceği ve inek sütüne ve diğer sütlere alerjisi olanlar için etkili bir alternatif olduğu öne çıkan bulgulardır. Ayrıca eşek sütü koroner arter hastalığ tedavisinde, erken yaşlanmada ve hipokolesterolemik (kanda kolesterol düzeyinin normalin altına düşmesi) diyetlerde kullanılabileceği belirtilmiştir. Yine eşek sütü zengin miktarda vitamin, mineral ve poli-doymamış yağ asitleri içeriğiyle cilt bakımında kullanılabilmekte olduğu bildirilmiştir. Altomonte, (2019) Journal of Dairy Research (süt araştırmaları dergisi) yazısında Avrupa ve özellikle İtalya'daki eşek sütü üretimine değinmiştir. Son yıllarda eşek sütü üretiminin artığını ama bunun yeterli olmadığını söyleyen yazar, eșek sütünün özellikle inek sütü alerjisi olan kişilere alternatif olarak sunulabileceğine değinmiştir. Ayrıca eşek sütünün sağlı̆̆ımızı iyileştirebilir bir yapıya sahip olduğu ve bu yüzden eșek sütü üretimini arttırmamız konusunda önerilerde bulunmuştur. Literatürde de görüldüğü gibi eşek sütünün insan sağlığına çeşitli faydalarının olduğu sonucu ortaya çıkmıştır. Ayrıca çalışmanın bir diğer amacı olan Kırgızistan'ın Bişkek şehrine $10 \mathrm{~km}$ uzaklıkta bulunan Beş-Kungey köyünde doğal ortamlarında yaşayan eşeklerin sütünün içeriği incelenmiştir. Doğru sonuçları elde etmek için analiz 3 kez tekrarlanmıştır. Analize ilişkin sonuçlar Tablo 4'teki gibidir.

Tablo 4. Kırgızistan' daki Eşeklerin Sütünün Analizi

\begin{tabular}{|l|c|c|c|c|}
\hline & $\mathbf{1 ~ k e z ,} \%$ & $\mathbf{2 ~ k e z , \%}$ & $\mathbf{3 ~ k e z , \%}$ & Ortalama,\% \\
\hline Yă & 0,5 & 0,6 & 0,5 & 0,5 \\
\hline Laktoz & 6,2 & 6,2 & 6,3 & 6,2 \\
\hline Asitlik & 5 & 5 & 5 & 5 \\
\hline pH & 7,3 & 7,4 & 7,3 & 7,3 \\
\hline Protein & 1,7 & 1,7 & 1,7 & 1,7 \\
\hline Kuru madde & 9,383 & 8,35 & 9,375 & 9,004 \\
\hline
\end{tabular}

Kaynak: Araştırmacı bilgisinde Razzakov ad.Kırgız Teknik Devlet Üniversitesi laboratuvarında yapılan analiz sonuçları 
Tablo 4'teki elde edilen veriler daha önce yapılan araştırmaların sonuçlarına benzemektedir. İncelenmiş eşek sütünün laktoz, yağ ve protein oranları Tablo 2'deki gibi olduğu görülmektedir. Özellikle, eşek ve kısrak sütünde düşük bulunan kazein ve $\beta$-laktoglobulin içeriğinin hipoalerjenik (alerjik reaksiyonlara daha seyrek sebep olan) süt ürünlerinde kullanımına olanak sağlamaktadır. Aynı zamanda anne sütünden kesilen ve alerjik reaksiyonları olan bebeklerde takviye gıda olarak kullanılabilir.

\section{Sonuç ve Öneriler}

Bugüne kadar yapılan araştırmalara göre eşek sütü, anne sütüne ve kısrak sütüne yakın olduğu ispatlanmıştır (Nikkhah, 2011; Öztürkoğlu, 2012; Polidori, 2012; Muehlhoff, 2013; Mathusudan ve diğ., 2017; Li ve diğ. 2017). Eşek sütü anne sütüne yakın, lakin inek sütünden farklı bileşimi ve yapısal özellikleri bileşimi ve yapısal özellikleri nedeniyle anne sütü yerine geçebilecek doğru bir alternatif olmaktadır (Budak ve Gürsel, 2012). Aynı zamanda eşek sütünün inek sütüne göre daha az alerjik reaksiyonlarının olduğu sonucu ortaya çıkmıştır. Eşek sütü sindirim sistemi rahatsızlıklarında, tümör tedavisinde, astım hastalıklarında erken yaşlanmada, obezite tedavisinde, akciğer kanseri tedavisinde, kardiyovasküler hastalarında, safra taşı tedavisinde, dişlerin güçlendirilmesine ve eklem ağrıları, astım, mide ülseri, boğaz ağrısı gibi hastalıkların tedavisinde kullanılabilir olduğu ilgili literatürde görülmüştür ( Nikkhah, 2011; Karabagias ve Halatsi, 2017; Mathusudan ve diğ., 2017; Li ve diğ., 2017; Altomonte, 2019).

Kırgızistan halkı çok eski tarihlerden günümüze kadar at sütünü çeşitli amaçlarla kullanmıştır. Bu amaçlardan en çok öne çıkan ise sağlıktır. Kırgızlar kaybettikleri sağlıklarını kazanabilmek ve güçlenmek için kımızı bir şifa olarak görmekte ve bazı hastalıkları kımızla tedavi etmektedirler (Akbulut, 2015). Günümüzde ise bu geleneklerini modern tesislerde sürdürmektedirler. Görsel 1 'de görüldüğü gibi Kırgızistan'ın çeşitli yerlerinde kımız tedavisi almak mümkündür. Bu gerçekliğe karşın son yıllarda Eşek sütü gitgide popüler olmaya başlamıştır. Yapılan araştırmalar ve tanıtımlar eşek sütünün faydalarına değinmekte ve kullanılmasının sağlığa yararlı olduğunu söylemektedir. Bu kapsamda Kırgızistan'daki at sütü tedavisinin yanında eşek sütü tedavisi uygulanması turistler açısından alternatifi artırarak bir çekicilik unsuru oluşturacaktır. Bunun yanında eşek sütünün geliştirilmesi ve kullanılabilmesi için geliştirilen öneriler şu şekildedir:

- Eşek sütünün yaşlanmayı yavaşlatma ve kırışıkları giderici özellikleri ön planda olan eşek sütü ürünleri (eşek sütü kremi, sabunu vb.) üretilip gelen turistlere satılabilir ve yerel ekonomiye katkı sağlanabilir.

- Kurort ve kımız tedavisi uygulayan tesislerin at sütü ve kımız tedavisine alternatif olarak eşek sütünü bulundurarak tedavi amaçlı hastalara sunabilirler.

- Üniversitelerin eşek sütüyle ilgili Ar-Ge faaliyetleri yürüterek insan sağlığına faydalı eşek sütünden yoğurt, kefir vb. ürün üretme yolları aramalıdır.

- Devletin Kırgızistan'da eşek sütü üretilebilecek tesisleri kurması ve yasal olarak eşek çiftliklerinin kurulmasına destek vermesi sağlanmalıdır.

- Eşek sütünün sağlığa yararları ve tedavi amaçlı kullanımı için reklamlar yapılmalı ve bu konuda seminerler verip kamuoyuna tanitılmalıdır.

Sonraki araştırmalarda Kırgızistan dışındaki diğer ülkelerde de benzer araştırmaların yürütülmesi ilgili literatüre katkı sağlayacaktır. 


\section{Kaynakça}

Altomonte, I. (2019). Donkey milk can improve our health, and that's why we should increase donkey milk production, Journal of Dairy Research (86), 135.

Belek, K. (2017). Göçebe Uygarlığı Işığında Türk Atının Yetiştirilmesi ve Mülkiyeti (Kırgız Kültürü Örneğinde), Uluslararası Türkçe Edebiyat Kültür Eğitim Dergisi, 6(2), 1043-1057.

Budak, Ö. Ş ve Gürsel, A. (2012). Alternatif Bir Süt: Eşek Sütü, Gıda, 37(4), 243-250.

Çevirgen, M. (2014). Medikal Turizm Destinasyonu Yönetimi Kamu-Özel Karşılaştırılması: Bursa İli Destinasyonu, Yüksek Lisans Tezi. Beykent Üniversitesi Sosyal Bilimler Üniversitesi, İstanbul.

Erdem, B., Gülcan, B. ve Chykynov, S. (2015). Konaklama İşletmelerinde Spa \& Wellness Hizmetlerinde Çalışan İşgörenlerin Profili: Antalya'daki Beş Yıldızlı Otel İşletmelerinde Bir Araştırma, Akademik Bakıs Dergisi, (48), 238-257.

Erdem, B. ve Gündoğdu, İ. (2018). Kumiss Treatment in the Context of Health Tourism: A Research in Kyrgyzstan, International Journal of Medical Research \& Health Sciences, 7(11), 135-155.

Irmak, N. (2016). Anne Sütünün Önemi ve İlk 6 Ay Sadece Anne Sütü Vermeyi Etkileyen Unsurlar, Jour Turk Fam Phy, 07(2): 27-31. Doi: 10.15511/tjtfp.16.02627

İçöz, O. (2009). Sağlık Turizmi Kapsamında Medikal (Tıbbi) Turizm ve Türkiye'nin Olanakları, Journal Of Yaşar University, 4(14), 2257-2279.

Karatosidi, D. (2013). Modern Use Of Donkeys, Iranian J. of Applied Animal Science, 1(3), 13-17.

Karabagias, L. K. ve Halatsi, E. Z. (2017). Donkey Milk Exploitation: Health Benefits, Potential Applications and Prospective Invigoration of the Hellenic Economy. Agri Res \& Tech: Open Access J. 12(5): 555863. DOI: 10.19080/ARTOAJ.2017.12.555863.

Kozak, N. ve Kozak, M. (2014). Genel Turizm, İlkeler, Kavramlar, Detay Yayınc1lık, 16 Baskı.

Kördeve, M.K. (2016). Sağlık Turizmine Genel Bir Bakış ve Türkiye'nin Sağlık Turizmindeki Yeri, Uluslararası Sağlık Yönetimi ve Stratejileri Araştırma Dergisi, 2(1), 51-61.

Li, L., Liu, X. ve Guo (2018). The nutritional ingredients and antioxidant activity of donkey milk and donkey milk powder, Food Sci Biotechnol, 27(2), 393-400.

Madhusudan, N. C., Ramachandra, C. T., Udaykumar, N. Sharnagouda, H. Nagraj, N. ve di $\breve{g}$. (2017). Composition, Characteristics, Nutritional value and Health Benefits of Donkey Milk-A Review. Dairy Science \& Technology, Dairy Science \& Technology, EDP sciences/Springer, 1-23.

Nikkhah, A. (2011). Equidae, Camel, And Yak Milks As Functional Foods: A Review, Journal Nutrition Food Science, 1(5), 2-7.

Öztürkoğlu, B. (2012). An Alternative Milk: Donkey Milk, The Journal of Food, 37(4), 243250.

Polidori, P. ve Vincenzetti, S. (2010). Difference Of Protein Fractions Among Fresh, Frozen And Powdered Donkey Milk, Recent Patents on Food, Nutrition \& Agriculture, 2(1), 56 - 60.

Sağlık Turizmi Derneği, Türkiye Sağlık Vakfi. (2010). Dünya'da ve Türkiye'de Sağlık Turizmi, Durum Tespit Raporu ve Çözüm Önerileri.

Salimei, E. ve Fantuz, F. (2012). Equid Milk For Human Consumption, International Dairy Journal, 24(2), $130-142$.

Tegin, R.A.A ve Gönülalan, Z. (2014). Bütün Yönleriyle Doğal Fermente Ürün Kımız, Manas Journal of Enginering, (2)1, 21-34.

July-2020 Vol:5 No:1 International Journal of Turkic World Tourism Studies 
Tsakali, E., Bosdra, K., Giannopoulos, N. R., Koulouriset, S. ve diğ. (2017). A Preliminary Study on the Development of Donkey Milk Based Fermented Product, Scientific Rewiews \& Chemical Communications, 7(3), 1-7.

Yirik, Ş. (2014). Sağlık Turizmi Üzerine Antalya Destinasyonunda Bir Araştırma, Doktora Tezi, Akdeniz Üniversitesi Sosyal Bilimler Enstitüsü, Turizm İşletmeciliği ve Otelcilik Ana Bilim Dalı, Antalya.

Zengingönül, O., Emeç, H., İyilikçi, D.E. ve Bingöl, P. (2012). Sağlık Turizmi: İstanbul'a Yönelik Bir Değerlendirme, Ekonomistler Platformu İstanbul Kalkınma Ajansı, İstanbul.

Чиркина, Е.Ю. (2004). Особенности гуморального иммунного ответа к белкам коровьего молока у больных с пищевой непереносимостью: автореф. дис. канд. мед. наук (Doktora Tezi) Электронная библиотека диссертаций veri tabanından erişilmiş̧ir, Москва.

\section{İnternet Kaynakçası}

Akbulut, U. (2015). Kımız: Orta Asya'nın Binlerce Yıllık İçeceği, http://www.uralakbulut.com.tr/wpcontent/uploads/2015/03/KIMIZ-ORTA-ASYANIN-BINNLERCE-YILLIK-İCECEĞİ-1-MART2015.pdf, (10.10.2017).

Attia, V. İ. (2017). Donkeys in Ancient Egypt, https://www.researchgate.net/publication/319122526_httpswwwacademiaedu34228771Donkeys_in Ancient_Egypt_Donkeys_in_Ancient_Egypt, (08.12.2019).

Barnato, K. (2018). Top Destinations for Health Tourism, https://www.cnbc.com/2014/03/12/top-destinationsfor-health-tourism.html?slide=1, (05.07.2018).

Blench, R. (2012). Wild Asses And Donkeys In Africa: Interdisciplinary Evidence For Their Biogeography, History And Current Use, Revised and updated version of a paper presented at SOAS, 9th May 2012. http://www.rogerblench.info/Ethnoscience/Animals/Livestock/Donkeys\%20SOAS\%202013.pdf (30.12.2019).

Henderson, A. (2014). The 10 Best Countries For Medical Tourism And Overseas Healthcare, nomadcapitalist.com, http://nomadcapitalist.com/2014/01/05/top-5-best-countries-medicaltourism/ (01.07.2018).

http://www.sayakat.kg/ru/pansionaty/kumysolechenie.html, (19.03.2018).

Karagözlü, C. (2003). Kımız Üretim Tekniği, Çiftçi Broşürü:45, Ege Üniversitesi Tarımsal Uygulama ve Araştırma Merkezi, http://agr2.ege.edu.tr/files/depo/ciftci_brosur/KimizuretimTeknigi.doc, (10.03.2018).

Kırdar, S. (2017). Kısrak Sütü, Mehmet Akif Ersoy Üniversitesi http://www.sutdunyasi.com/makaleler/bilimsel/kisrak-sutu-kimiz (Erişim: 5 Nisan 2017).

Kırgız Cumhuriyeti Milli İstatistik Komitesi Turizm Verileri, (2016). http://stat.kg/ (19.07.2018).

Laleli (2016). Türkiye'nin Dört Yanına Eşek Sütü Satıyor, htttp://www.hurriyet.com.tr/turkiyenin-dort-yaninaesek-sutu-satiyor-40040798, Antalya - DHA. (Erişim: 09.10.2017).

Polidori, P. (2012). Nutritional Qualities Of Donkey Milk, School of Pharmacy, Univ. of Camerino, Italy; School of Veterinary Medical Sciences, Univ. of Camerino, https://www.soas.ac.uk/history/conferences/donkey-conference-2012//archive-of-previouspapers/file86174.pdf. (5 Nisan 2017).

Riskulova, T., ve Mihaylova, E. (2017). Kımız Tedavisi, sputnik.kg: https://ru.sputnik.kg/infographics/20170525/1033394423/kumysolechenie-v-kyrgyzstane.html, (Erişim: 19.03.2018). 
Türsab Sağlik $\quad$ Turizmi $\quad$ Raporu, https://onedrive.live.com/view.aspx?cid=9bbfa4347dd80b625\&id=documents\&resid=9BBFA4347D 80B625\%21431\&app=WordPdf\&authkey=ACdcb6Jt0OxWSh0\& (Erişim: 09.10.2017).

World Health Organization (2013). http://apps.who.int/iris/bitstream/10665/82058/1/WHO_HIS_HSI 13.1_eng.pdf?ua=1_(Erişim: 09.10.2017). 